\title{
Climate Change Impact On Rice Production in Pakistan: An ARDL-Bounds Testing Approach to Cointegration
}

\author{
Abbas Ali Chandio ${ }^{1}$, Yuansheng Jiang ${ }^{1,}$, , Habibullah Magsi ${ }^{2}$ \\ ${ }^{1}$ College of Economics, Sichuan Agricultural University, Chengdu, China;3081336062@qq.com; \\ yjiang@sicau.edu.cn \\ ${ }^{2}$ Department of Agricultural Economics, Sindh Agriculture University, Tandojam, Pakistan; \\ magsihabib@gmail.com \\ *Correspondence: yjiang@sicau.edu.cn; Tel.: +8615928868178
}

\begin{abstract}
This research paper aims to examine the relationship between $\mathrm{CO}_{2}$, temperature, area, fertilizers and rice production in Pakistan. This study used Augmented Dickey Fuller (ADF) and Phillips Perron (PP) unit root tests to check the order of integration of each variable. The cointegration analysis with ARDL bounds testing approach is used to examine the impact of climate change on rice production in Pakistan over time series data from the period 1968 to 2014. The parameter stability test of the model is also checked at the end. The results of estimation show that the important variables of the study are cointegrated demonstrating the presence of long-run association among them. Furthermore, climate change factors, e.g. $\mathrm{CO}_{2}$ and temperature have a long-run and short-run positive effect on the production of rice in Pakistan. This present work is original and it is first time empirically tested the impact of climate change on rice production in Pakistan. The annual time series data of 47 years enhances the validity of the empirical findings. The most fruitful finding of this research is that rice production in Pakistan is positively influenced by emission of carbon dioxide $\left(\mathrm{CO}_{2}\right)$ at 5 percent significance level in both long-run and short-run.
\end{abstract} Keywords: Pakistan; Climate change; Rice production; ARDL 


\section{Introduction}

Climate plays holistically significant role for agricultural productivity. In fact, many plant species are temperature sensitive; where increase in global temperature had adverse effects on the crops as well as the agriculture. During 2011, Pakistan's agriculture was severely affected by the weather changes, where in 2010 the country was addressed as the top most country in the world affected by climate related disasters (Siddiqui et al. 2012; Ali et al., 2017). The rice production is expected to be influenced by unseen future changes associated with global warming temperature, carbon dioxide and rainfall. Because of climate change, its rapid effects can be noticed in the shape of adverse effects of extreme weather conditions on the production systems of rice and food security. Previous studies show the fact that the climate change causing increase in temperature and simultaneously adverse affects on rice crop and ultimately decrease the crop productivity and its quality (Joyo et al., 2018). It was revealed by a comprehensive simulation research that the climate change since 1960 s decreased yield of rice by $12.4 \%$, but with largest contribution coming from lowering radiation. The positive and negative yield response in different regions was demonstrated through statistical analysis between climate variables and observed yield. Variations in mean temperatures, increasing weather changes and rising sea level predicted less but possibly even more significant effect on rice production. In Pakistan, about 11 percent total agricultural area of the country is rice crop mainly based on Basmati and IRRI varieties (Nomman, and Schmitz, 2011; Ali et al., 2017). Whereas, about 90 percent of the produce is coming from Sindh and Punjab provinces of Pakistan (GOP, 2018; Chandio and Jinag, 2018). The rice is considered as staple diet of the local habitats as well as it is one of the source of foreign exchange earnings. The country mostly exports rice to Saudi Arabia, United Arab Emirates (UAE), Afghanistan and Iran (Chandio et al., 2017). Recent trends of rice productivity in Pakistan show the crop cultivation is declining since last decade. This negative impact is might be due to weather changes (Joyo et al., 2018), and or land degradation (Magsi and Sheikh, 2017). In Pakistan a number of researchers (for instance, Hanif et al., 2010; Rasul et al., 2012; Zhu et al., 2013) have examined the effects of climate change on agriculture. Additionally, several previous studies on adaptation of agriculture to climate change in Pakistan (for example, Ali and Erenstein, 2017; Abid et al., 2018 \& 2017; Arshad et al., 2016, 2017; Gorst et al., 2015). The available literature has reported that there limited adaptation of climate change at farm level and emphasized the need for more research to examine the factors 
affecting local understanding of climate change and adaptation behavior. However, the present empirical study is different from previous studies. Therefore, this research project was initiated to evaluate the relationship between temperature, area under rice crop, fertilizer application, and $\mathrm{CO}_{2}$, impacts on rice production in Pakistan by using ARDL bounds testing cointegration approach. This article is comprised over the detailed methodology adapted for this research project, main findings as well as the policy prospects have been suggested based on the results.

\section{Data and methodology}

We used a number of an important variables for this empirical study. The dependent variable is rice production while independent variables we used several climatic variables such as emission of carbon dioxide $\left(\mathrm{CO}_{2}\right)$ and average temperature. This study also considered other control variables like as area under rice crop and fertilizers offtake. The annual time series data from 19682014 for rice production, area under rice crop and fertilizers offtake are obtained from different sources (see Table 1). The collected data has been analyzed by using computer program like Eviews 9.

Table 1. Variables and data sources.

\begin{tabular}{llll}
\hline Variables & Description & Units of measurements & Sources \\
\hline RP & Rice production & Thousand tons & GOP \\
$\mathrm{CO}_{2}$ & Emission of carbon dioxide & Thousand metric tons & WDI \\
$\mathrm{T}$ & Average temperature & Celsius degree centigrade & WDI \\
$\mathrm{A}$ & Area under rice crop & Thousand hectares & GOP \\
$\mathrm{F}$ & Fertilizers offtake & Thousand nutrient tons & GOP \\
\hline
\end{tabular}

\section{1. Methodology}

In order to examine the effects of climate change on rice production, there is a need to use reasonable approach for empirical estimation. In past, a number of research work used Engle and Granger (1987) and Johansen and Juselius (1990) co-integration approaches for testing the cointegration amongst the study variables in the long-run. Our study also has adopted Johansen and Juselius (1990) approach for checking the co-integration. For doing so, the important variables of the study should be incorporated at same array. Consequently, to solve this problem the Autoregressive Distributed Lag (ARDL) approach developed by Pesaran, et al. (2001) can be used to cointegration. The ARDL approach tests the cointegration linkage, devoid of considering the 
same order of integrated of the series which are either integrated at 1(0), 1(1) or are mutually integrated. This empirical study is based on annual time series data. Normally annual time series data have the issue of non stationarity. A number of approaches used to check the issue of stationarity, i.e. DF-GLS by Elliot et al. (1996), KKPS by Kwiatkowski et al. (1992), Ng-Perron by Ng-Perron (2001), ADF by Dickey and Fuller (1979) and PP by Philip and Perron (1988), respectively. However, in this paper, Augmented Dicky Fuller test (ADF) and Phillips Perron test (PP) to check stationarity of the series. Additionally, if the series are integrated at I $(0)$ or I $(1)$ or the mixture of both, the Autoregressive Distributed Lag (ARDL) approach can be used to examine the long-run relationship between the study variables. Likewise, if the series indicates the cointegration linkage in the long-run, the next step of the study is to use the Error Correction Mechanism (ECM) for investigating the short-run dynamics of the variables.

\section{2. The Autoregressive Distributed Lag (ARDL) approach}

The ARDL approach is very much popularized by Pesaran and Pesaran (1997), this approach has a number of advantages as compared to previous cointegration approaches like as Engle and Granger (1987), maximum likelihood-based approach by Johansen and Juselius (1990). For checking the existence of long-run relationship by the ARDL approach is easy without considering the series which are integrated at levels I( 0$)$ or at first difference I( 1$)$ or mixed order of integration. The ARDL approach as it is very much reliable in case of small sample sizes and avoids the issues of endogeneity and help to investigate the coefficients in the long-run. The ARDL-F-statistics is used to examine the presence of long-run association between the variables. The critical values of ARDL-F-statistics are available with lower and upper bounds (Table 4) in Pesaran (1997) and Pesaran et al. (2001). If the ARDL-F-statistics is smaller than the LCB then the null hypothesis of cointegration cannot be rejected, however, if it is greater than UCB then the null hypothesis is rejected. The outcomes within the bound limits are inconclusive. After checking the cointegration between the study variables, we run the model in Akaike information criteria or Schwarz Bayesian criteria or Hannan-Quinn information criterion in order to investigate the long-run linkage between the variables. Afterward, this empirical study also estimate the Error Correction Model (ECM) ${ }^{1}$.

\subsection{Specification of the Model}

${ }^{1} \mathrm{LCB}$ represents Lower Critical Bound (LCB) and UCB represents Upper Critical Bound (UCB). 
The null hypothesis of this empirical study is that climate change do not have positive impact on rice production. This hypothesis is estimated by the ARDL bounds testing approach to cointegration on the subsequent equation. The linkage of rice production with the important variables of the study is specified as follows:

Rice Production $=\beta_{0}+\beta_{1} \mathrm{CO}_{2}+\beta_{2} T+\beta_{3} A+\beta_{4} F+\varepsilon_{t}$

The linear combination has been converted into log-linear model which gives suitable and proficient results as compared to the simple linear model. The equation (1) can be transformed into $\log$ as follows:

$\ln R P=\beta_{0}+\beta_{1} \ln C O_{2}+\beta_{2} \ln T+\beta_{3} \ln A+\beta_{4} F+\varepsilon_{t}$

Here, we have taken the $\log (\ln )$ of all the study variables, where RP represents rice production, $\mathrm{CO}_{2}$ represents emission of carbon dioxide, $\mathrm{T}$ represents average temperature, A represents area under rice crop, F represents fertilizers offtake and $\varepsilon_{\mathrm{t}}$ represents standard error term. Now, in order to investigate the long-run linkage between dependent and independent variables of the study through the ARDL bounds testing approach to cointegration. The equation (3) of the model is as follows:

$$
\begin{aligned}
\Delta \ln R P_{t}=\beta_{0} & +\sum_{k=1}^{n} \beta_{1 k} \Delta \ln R P_{t-k} \\
& +\sum_{k=1}^{n} \beta_{2 k} \Delta \ln C O_{2_{t-k}}+\sum_{k=1}^{n} \beta_{3 k} \Delta \ln T_{t-k}+\sum_{k=1}^{n} \beta_{4 k} \Delta \ln A_{t-k}+\sum_{k=1}^{n} \beta_{5 k} \Delta \ln F_{t-k} \\
& +\lambda_{1} \ln R P_{t-1}+\lambda_{2} \ln C O_{2 t-1}+\lambda_{3} \ln T_{t-1}+\lambda_{4} \ln A_{t-1}+\lambda_{5} \ln F_{t-1}+\varepsilon_{t}
\end{aligned}
$$

Now; based on the ARDL approach the equation (3) is established for ordinary least square (OLS) method. The null hypothesis of this empirical is tested as follows:

$$
H_{0}=\lambda_{1}=\lambda_{2}=\lambda_{3}=\lambda_{4}=\lambda_{5}=0
$$

Against it's the alternative hypothesis is tested as follows:

$$
H_{1} \neq \lambda_{1} \neq \lambda_{2} \neq \lambda_{3} \neq \lambda_{4} \neq \lambda_{5} \neq 0
$$


The following error correction model (ECM) in ARDL formulation is applied to estimate the shortrun relationship amid rice production, emission of carbon dioxide, average temperature, area under rice crop and fertilizers offtake; the equation (4) is formulated as follow:

$$
\begin{aligned}
\Delta \ln R P_{t}=\beta_{0} & +\sum_{k=1}^{n} \beta_{1 k} \Delta \ln R P_{t-k} \\
& +\sum_{k=1}^{n} \beta_{2 k} \Delta \ln C O_{2_{t-k}}+\sum_{k=1}^{n} \beta_{3 k} \Delta \ln T_{t-k}+\sum_{k=1}^{n} \beta_{4 k} \Delta \ln A_{t-k}+\sum_{k=1}^{n} \beta_{5 k} \Delta \ln F_{t-k} \\
& +\alpha E C T_{t-1}+\varepsilon_{t}
\end{aligned}
$$

\section{Empirical findings and discussion}

\subsection{Preliminary analysis: Descriptive statistics, Correlation matrix and Unit root tests}

The annual time series data in this empirical study have been used to estimate impact of climate change on rice production in Pakistan. Table 2 reports the descriptive statistics for an important study variables employed in the analysis. Results shows that all the important study variables are normally distributed with constant variance and zero covariance as showed by Jarque-Bera statistics. Likewise, Table 3 indicates the correlation matrix. The correlation analysis reveal that emission of carbon dioxide, average temperature, area under rice crop, fertilizers offtake are positively correlated with rice production. This study also found a positive correlation between fertilizers offtake, area under rice crop and average temperature with emission of carbon dioxide.

Table 2. Summary statistics (before taking logarithm).

\begin{tabular}{lccccc}
\hline Variable & $\mathrm{RP}$ & $\mathrm{CO}_{2}$ & $\mathrm{~T}$ & $\mathrm{~A}$ & $\mathrm{~F}$ \\
\hline Mean & 3851.926 & 0.629820 & 20.26573 & 2067.068 & 2032.301 \\
Median & 3429.700 & 0.636761 & 20.25820 & 2097.000 & 1892.880 \\
Maximum & 6952.000 & 0.991030 & 21.14000 & 2963.000 & 4360.000 \\
Minimum & 1498.700 & 0.308601 & 19.39500 & 198.5000 & 68.70000 \\
Std. Dev. & 1338.768 & 0.219164 & 0.495475 & 475.2983 & 1235.286 \\
Skewness & 0.624237 & 0.098907 & -0.048935 & -1.114252 & 0.122985 \\
Kurtosis & 2.636085 & 1.637933 & 1.927233 & 6.433371 & 1.882294 \\
Jarque-Bera & 3.311784 & 3.709781 & 2.272465 & 32.81044 & 2.564963 \\
Probability & 0.190922 & 0.156470 & 0.321026 & 0.000000 & 0.277348 \\
Observations & 47 & 47 & 47 & 47 & 47 \\
\hline
\end{tabular}


Note: $R P$ represents rice production, $\mathrm{CO}_{2}$ represents emission of carbon dioxide, $T$ represents average temperature, A represents area under rice crop and $F$ represents fertilizers offtake, respectively.

Table 3. Correlation Matrix.

\begin{tabular}{|c|c|c|c|c|c|}
\hline $\begin{array}{l}\text { Correlation } \\
\text { t-Statistic } \\
\text { Probability }\end{array}$ & $\operatorname{lnRP}$ & $\operatorname{lnCO} 2$ & $\ln \mathrm{T}$ & $\ln \mathrm{A}$ & $\ln F$ \\
\hline $\operatorname{lnRP}$ & $\begin{array}{c}1.000000 \\
----\end{array}$ & & & & \\
\hline $\operatorname{lnCO} 2$ & $\begin{array}{c}0.867813 \\
11.71579 \\
0.0000\end{array}$ & $\begin{array}{c}1.000000 \\
---- \\
----\end{array}$ & & & \\
\hline $\ln \mathrm{T}$ & $\begin{array}{c}0.607420 \\
5.129397 \\
0.0000\end{array}$ & $\begin{array}{c}0.595737 \\
4.975629 \\
0.0000\end{array}$ & $\begin{array}{c}1.000000 \\
----- \\
-----\end{array}$ & & \\
\hline $\ln \mathrm{A}$ & $\begin{array}{c}0.519305 \\
4.076347 \\
0.0002\end{array}$ & $\begin{array}{c}0.455155 \\
3.429054 \\
0.0013\end{array}$ & $\begin{array}{c}0.264481 \\
1.839702 \\
0.0724\end{array}$ & $\begin{array}{c}1.000000 \\
---- \\
----\end{array}$ & \\
\hline $\operatorname{lnF}$ & $\begin{array}{c}0.803227 \\
9.045573 \\
0.0000\end{array}$ & $\begin{array}{c}0.741636 \\
7.416568 \\
0.0000\end{array}$ & $\begin{array}{c}0.397637 \\
2.907143 \\
0.0056\end{array}$ & $\begin{array}{c}0.371350 \\
2.682943 \\
0.0102\end{array}$ & $\begin{array}{c}1.000000 \\
----- \\
----\end{array}$ \\
\hline
\end{tabular}

In order to test stationarity of the study variables we have employed Augmented Dickey-Fuller (ADF) and Philips-Perron (PP) unit root tests. The results of both unit root tests are displayed in Table 4 show that rice production $(\operatorname{lnRP})$, average temperature $(\ln T)$, area under rice crop $(\ln A)$ and fertilizer offtake $(\operatorname{lnF})$ are stationary at levels $\mathrm{I}(0)$ and emission of carbon dioxide $\left(\operatorname{lnCO} \mathrm{O}_{2}\right)$ is integrated of the first order I(1) with intercept and trend.

Table 4. Results of Unit Root Test.

\begin{tabular}{lcccccc}
\hline & \multicolumn{2}{c}{ ADF } & \multicolumn{5}{c}{ P-P } \\
\hline Variables & At level & $\Delta$ & $\mathrm{I}$ & At level & $\Delta$ & $\mathrm{I}$ \\
\hline $\operatorname{lnRP}$ & $-5.296916^{\mathrm{a}}$ & - & $\mathrm{I}(0)$ & $-5.335647^{\mathrm{a}}$ & - & $\mathrm{I}(0)$ \\
$\operatorname{lnCO}{ }_{2}$ & -2.793905 & $-5.380144^{\mathrm{a}}$ & $\mathrm{I}(1)$ & -2.914978 & $-5.380144^{\mathrm{a}}$ & $\mathrm{I}(1)$ \\
$\operatorname{lnT}$ & $-5.950189^{\mathrm{a}}$ & - & $\mathrm{I}(0)$ & $-5.948534^{\mathrm{a}}$ & - & $\mathrm{I}(0)$ \\
$\ln \mathrm{A}$ & $-5.365850^{\mathrm{a}}$ & - & $\mathrm{I}(0)$ & $-5.198640^{\mathrm{a}}$ & - & $\mathrm{I}(0)$ \\
$\operatorname{lnF}$ & $-5.677314^{\mathrm{a}}$ & - & $\mathrm{I}(0)$ & $-5.664846^{\mathrm{a}}$ & - & $\mathrm{I}(0)$ \\
\hline
\end{tabular}


Note: ${ }^{a}$ denotes $1 \%$ level of significance.

\subsection{Selection of lag order}

The exclusive integrating order of the time series properties of the variables tends to lead us to use the ARDL bounds approach to check whether cointegration exists or not amongst the important variables of this study like as rice production $(\operatorname{lnRP})$, emission of carbon dioxide $\left(\ln \mathrm{CO}_{2}\right)$, average temperature $(\ln \mathrm{T})$, area under rice crop $(\ln \mathrm{A})$ and fertilizers offtake $(\ln F)$, respectively. After checking integration of the variables, next step of this study is to select appropriate lag order of the variable to employ ARDL bounds testing approach to cointegration. The appropriate lag order ascertained by sequential modified LR test statistic (LR), Final Prediction Error (FPE), Akaike Information Criterion (AIC), Schwarz information criterion (SC), and Hannan-Quinn information criterion (HQ). The empirical evidence in Table 5 showed that the lag order is set as 1 by most criterions.

Table 5. Table 3: Optimal lag orders of VAR (vector autoregression) model.

\begin{tabular}{lllllll}
\hline Lag & LogL & LR & FPE & \multicolumn{1}{c}{ AIC } & \multicolumn{1}{c}{ SC } & \multicolumn{1}{c}{ HQ } \\
\hline 0 & 62.86750 & NA & $4.66 \mathrm{e}-08$ & -2.691511 & -2.486721 & -2.615991 \\
1 & 172.4076 & $188.5108^{\mathrm{a}}$ & $9.23 \mathrm{e}-10^{\mathrm{a}}$ & $-6.623607^{\mathrm{a}}$ & $-5.394863^{\mathrm{a}}$ & $-6.170485^{\mathrm{a}}$ \\
2 & 188.7428 & 24.31295 & $1.45 \mathrm{e}-09$ & -6.220596 & -3.967899 & -5.389871 \\
3 & 208.5285 & 24.84710 & $2.10 \mathrm{e}-09$ & -5.978069 & -2.701417 & -4.769741 \\
4 & 233.4145 & 25.46481 & $2.76 \mathrm{e}-09$ & -5.972769 & -1.672164 & -4.386839 \\
\hline
\end{tabular}

Note: ${ }^{a}$ indicates lag order selected by the criterion.

\subsection{ARDL Bounds Testing Approach to Cointegration Analysis}

Proceeding to the cointegration test; the empirical results from the ARDL bounds testing approach to cointegration are presented in Table 6. The results revealed that our computed F-statistics i.e. $3.848,9.647,4.948$ and 5.484 exceeds the upper critical bound (UCB) limit at 10, 1 and 5 percent level of significance when rice production $(\operatorname{lnRP})$, average temperature $(\ln T)$, area under rice crop $(\ln \mathrm{A})$ and fertilizers offtake $(\ln \mathrm{F})$ have been used as dependent variables. It implies that there are four cointegration vectors and this study may reject the hypothesis of no cointegration. The empirical results of the ARDL bounds testing approach to cointegration confirms long-run

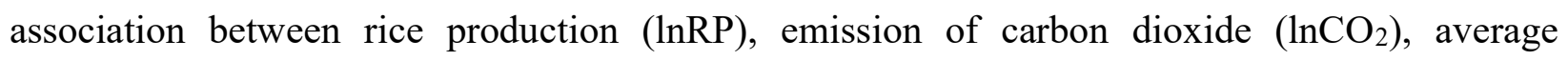
temperature $(\ln \mathrm{T})$, area under rice crop $(\ln \mathrm{A})$ and fertilizers offtake $(\ln F)$ in Pakistan over the period 1986-2014. In this study we have also applied Johansen and Juselius (1990) cointegration approach to test the robustness of long-run association amongst the selected variables. The results 
of Johansen cointegration approach are presented in Table 7 showed that there exists cointegration association amongst $\operatorname{lnRP}, \operatorname{lnCO} 2, \ln \mathrm{T}, \ln \mathrm{A}$ and $\ln \mathrm{F}$. It implies that the results of long-run are very much effective and robust. 
Table 6. Results of ARDL bounds testing to cointegration

\begin{tabular}{lccccc}
\hline Variable & LnRP & $\mathrm{LnCO}_{2}$ & $\mathrm{LnT}$ & $\mathrm{LnA}$ & $\mathrm{LnF}$ \\
\hline F-statistics & $3.8483^{\mathrm{c}}$ & 0.5344 & $9.6472^{\mathrm{a}}$ & $4.948^{\mathrm{b}}$ & $5.4848^{\mathrm{a}}$ \\
Optimal lag structure & $(1,0,0,1,0)$ & $(1,0,0,0,1)$ & $(1,1,0,1,1)$ & $(1,0,0,0,0)$ & $(1,0,1,0,0)$ \\
Critical values & $1 \%$ & $5 \%$ & $10 \%$ & & \\
Lower bounds I(0) & 3.74 & 2.86 & 2.45 & & \\
Upper bounds I(1) & 5.06 & 4.01 & 3.52 & & \\
Diagnostic tests & & & & & \\
$R^{2}$ & 0.3429 & 0.1214 & 0.5960 & 0.3763 & 4.8226 \\
$F^{2}$ statistics & $3.4789^{\mathrm{a}}$ & 0.9217 & $7.0089^{\mathrm{a}}$ & $4.9482^{\mathrm{a}}$ & $4.882^{\mathrm{a}}$ \\
$\chi^{2}$ NORMAL & $0.0845(0.9585)$ & $1.9364(0.3797)$ & $0.9016(0.6371)$ & $0.6786(0.1543)$ & $0.8325(0.4709)$ \\
$\chi^{2}$ SERIAL & $1.5432(0.2195)$ & $0.2197(0.8037)$ & $0.7980(0.4580)$ & $0.0598(0.9420)$ & $2.1934(0.1255)$ \\
$\chi^{2}$ ARCH & $2.1678(0.1271)$ & $0.1582(0.6927)$ & $0.2222(0.6397)$ & $0.0366(0.8490)$ & $1.9454(0.1556)$ \\
$\chi^{2}$ White & $0.9166(0.4931)$ & $1.9611(0.1044)$ & $0.4058(0.9516)$ & $0.4641(0.9564)$ & $0.3715(0.9906)$ \\
$\chi^{2}$ RESET & $0.5580(0.5770)$ & $0.9408(0.3526)$ & $0.1933(0.8478)$ & $1.6075(0.2134)$ & $1.2472(0.2665)$ \\
\hline
\end{tabular}

Note: ${ }^{\mathrm{a} / \mathrm{b} / \mathrm{c}}$ denotes the significant levels at $1 \%, 5 \%$, and $10 \%$ respectively 
Table 7. Results of the Johansen cointegration test.

\begin{tabular}{lccc}
\hline \multicolumn{3}{c}{ Trace Statistic } \\
\hline Hypothesis & Test Statistic & $5 \% \mathrm{CV}$ & P-value \\
\hline $\mathrm{r} \leq 0$ & $88.58881^{\mathrm{a}}$ & 69.81889 & 0.0008 \\
$\mathrm{r} \leq 1$ & $49.83721^{\mathrm{b}}$ & 47.85613 & 0.0322 \\
$\mathrm{r} \leq 2$ & 23.37693 & 29.79707 & 0.2280 \\
$\mathrm{r} \leq 3$ & 5.573942 & 15.49471 & 0.7452 \\
$\mathrm{r} \leq 4$ & 1.760661 & 3.841466 & 0.1845 \\
\hline \multicolumn{4}{c}{ Maximum Eigenvalue } \\
\hline Hypothesis & Test Statistic & $5 \% \mathrm{CV}$ & $\mathrm{P}$-value \\
\hline $\mathrm{r} \leq 0$ & $38.75160^{\mathrm{a}}$ & 33.87687 & 0.0121 \\
$\mathrm{r} \leq 1$ & 26.46028 & 27.58434 & 0.0691 \\
$\mathrm{r} \leq 2$ & 17.80299 & 21.13162 & 0.1374 \\
$\mathrm{r} \leq 3$ & 3.813281 & 14.26460 & 0.8785 \\
$\mathrm{r} \leq 4$ & 1.760661 & 3.841466 & 0.1845 \\
\hline Note: ${ }^{\mathrm{a}}{ }^{\mathrm{b}}$ denotes $1 \%$ and $5 \%$ level of significance, respectively
\end{tabular}

\subsection{Long-Run Estimates}

The long-run results of the effects of $\mathrm{CO}_{2}$, average temperature, area under rice crop and fertilizers offtake in Pakistan are presented in Table 8. In all, only temperature is found to have no significant impact on rice production in long-run. A small raises in temperature may create insignificant effect on rice production in Pakistan in the long-run. The country (Pakistan) is located next to the tropic region where a small raises in temperature due to climate variation may not have significant effect on rice production as compared to the tropical regions where already temperature is at threshold level. The finding of this study reveals that $\mathrm{CO}_{2}$ has a positive and significant effect on rice production in Pakistan. The estimated long-run coefficient of $\mathrm{CO}_{2}$ shows that at $5 \%$ level of significance, a $1 \%$ increase in $\mathrm{CO}_{2}$ will lead to a corresponding increase of about $0.34 \%$ in rice production. Our finding is consistent with Janjua et al. (2014). In addition, this paper discovers that rice production in Pakistan is positively influenced by area under cultivation at 5\% level of significance in long-run. An increase in the area under cultivation by $1 \%$ is expected to increase rice production by $0.14 \%$. This finding is consistent with (Hussain, 2012; Chandio et al., 2018a). Fertilizers is confirmed to exert positive impact on the rice production in Pakistan at a significance level of $5 \%$. An increase in the fertilizer consumption by $1 \%$ is expected to raise rice production by $0.11 \%$ in the long-run. Fertilizers have very much effect on crop productivity like it improve the land fertility and also it enhance plant growth. In the long-run fertilizers would enhance the available land fertility affecting to leads the crop productivity. In rural areas of Pakistan, most of 
farmers use both natural and chemical fertilizers to improve the fertility of the land. Chemical fertilizers play an important role to increase the rice production in Pakistan. This empirical evidence supports the findings of (Janjua et al., 2014; Chandio et al., 2018a; Chandio et al., 2018b) on the relationship between fertilizer consumption and food grain production for Pakistan.

Table 8. Results of long-run coefficients employing the ARDL approach.

\begin{tabular}{lcccc}
\hline & Dependent variable is lnRP: & ARDL $(1,0,0,1,0)$ & selected based on AIC \\
\hline Variable & Coefficient & Std. Error & T- Ratio & P-value \\
Ln CO $\mathrm{CO}_{2}$ & $0.344458^{\mathrm{b}}$ & 0.155825 & 2.210541 & 0.0328 \\
$\mathrm{Ln} \mathrm{T}$ & 2.132417 & 1.581831 & 1.348069 & 0.1852 \\
Ln A & $0.140403^{\mathrm{b}}$ & 0.071068 & 1.975613 & 0.0551 \\
Ln F & $0.117868^{\mathrm{b}}$ & 0.049545 & 2.379020 & 0.0222 \\
$\mathrm{C}$ & 0.073005 & 4.868952 & 0.014994 & 0.9881 \\
\hline
\end{tabular}

Note: ${ }^{b}$ indicates $5 \%$ level of significance

\subsection{Short-Run Association}

The short-run coefficients related with the long-run are estimated and the results are demonstrated in Table 9. In short-run analysis impact of climate change factors, e.g. $\mathrm{CO}_{2}$ and temperature have positive impact on rice production in Pakistan. The coefficients of short-run of $\mathrm{CO}_{2}$ and temperature show that $1 \%$ increase in $\mathrm{CO}_{2}$ can enhance the rice production by $0.16 \%$, whereas, $1 \%$ increase in temperature can increase the rice production by $1.03 \%$, respectively. Likewise, the short-run value of area under rice crop cultivation is statistically significant. In the short-run also area under rice crop cultivation will plays a vital role in boosting rice production in Pakistan. The finding shows that a $1 \%$ increase in area rice production will lead to a corresponding increase by $0.06 \%$. The findings of this study supports the findings of (Hussain, 2012; Janjua et al., 2014; Chandio et al., 2018a). Additionally, an estimated ECM is negative (-0.487500) and shows that at $5 \%$ level of significance. It was observed from Table 8 that the coefficient of ECM was found to be -0.487500 which reveals that adjustment takes place $0.48 \%$ per year towards the long run equilibrium. The values of $\mathrm{R}^{2}$ and Adjusted $\mathrm{R}^{2}$ were estimated to be $0.92 \%$ and $0.91 \%$, which suggests that our model is strongly good fitted. 
Table 9. Results of Short Run Error Correction.

\begin{tabular}{|c|c|c|c|c|}
\hline \multicolumn{5}{|c|}{ Dependent variable is lnRP: ARDL $(1,0,0,1,0)$ selected based on AIC } \\
\hline Variable & Coefficient & Std. Error & T- Ratio & P-value \\
\hline$\Delta \mathrm{Ln} \mathrm{CO}_{2}$ & $0.167923^{\mathrm{b}}$ & 0.080337 & 2.090230 & 0.0430 \\
\hline$\Delta \operatorname{Ln} \mathrm{T}$ & 1.039554 & 0.835800 & 1.243783 & 0.2208 \\
\hline$\Delta \operatorname{Ln} A$ & $0.068446^{\mathrm{b}}$ & 0.032886 & 2.081325 & 0.0438 \\
\hline$\Delta \mathrm{LnF}$ & -0.002627 & 0.027330 & -0.096137 & 0.9239 \\
\hline $\operatorname{ECM}(-1)$ & $-0.487500^{\mathrm{a}}$ & 0.113028 & -4.313083 & 0.0001 \\
\hline R-squared & 0.926237 & \multicolumn{2}{|c|}{ Mean dependent var } & 8.197669 \\
\hline Adjusted R-squared & 0.915173 & \multicolumn{2}{|c|}{ S.D. dependent var } & 0.348661 \\
\hline S.E. of regression & 0.101548 & \multicolumn{2}{|c|}{ Akaike info criterion } & -1.599969 \\
\hline Sum squared resid & 0.412479 & \multicolumn{2}{|c|}{ Schwarz criterion } & -1.324415 \\
\hline Log likelihood & 44.59928 & \multicolumn{2}{|c|}{ Hannan-Quinn criter. } & -1.496276 \\
\hline F-statistic & $83.71330^{\mathrm{a}}$ & \multicolumn{2}{|c|}{ Durbin-Watson stat } & 2.425227 \\
\hline
\end{tabular}

Note: ${ }^{\mathrm{a} / \mathrm{b}}$ denotes $1 \%$ and $5 \%$ level of significance, respectively

\subsection{Diagnostic and Parameter Stability test}

In this study the Autoregressive Distributed Lag (ARDL) model has good fitted and successfully passed all the tests of diagnostic (Table 10). The ARDL model also has passed the stability tests as demonstrated by the recursive residuals graphs (Figures 1 and 2).

Table 10. Diagnostic tests of the Model

\begin{tabular}{lcc}
\hline Test & F-statistic & P-value \\
\hline$\chi^{2}$ SERIAL & 2.009869 & 0.1480 \\
$\chi^{2}$ NORMAL & 0.118813 & 0.9423 \\
$\chi^{2}$ ARCH & 2.654643 & 0.1104 \\
$\chi^{2}$ White & 0.334384 & 0.9952 \\
$\chi^{2}$ RESET & 0.893374 & 0.3771 \\
CUSUM & Stable & \\
CUSUM Square & Stable & \\
\hline
\end{tabular}




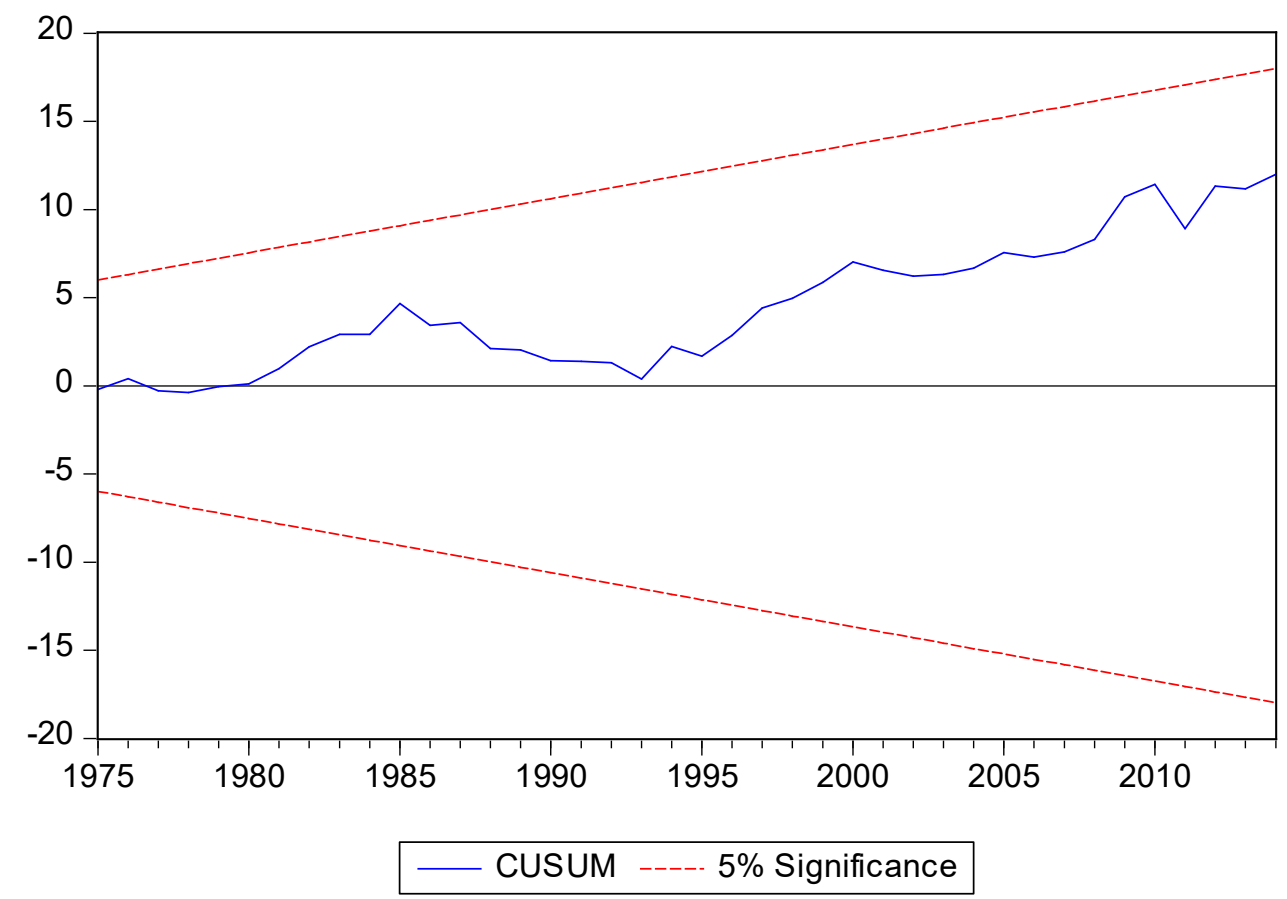

Figure-1: Plot of Cumulative Sum of Recursive Residuals

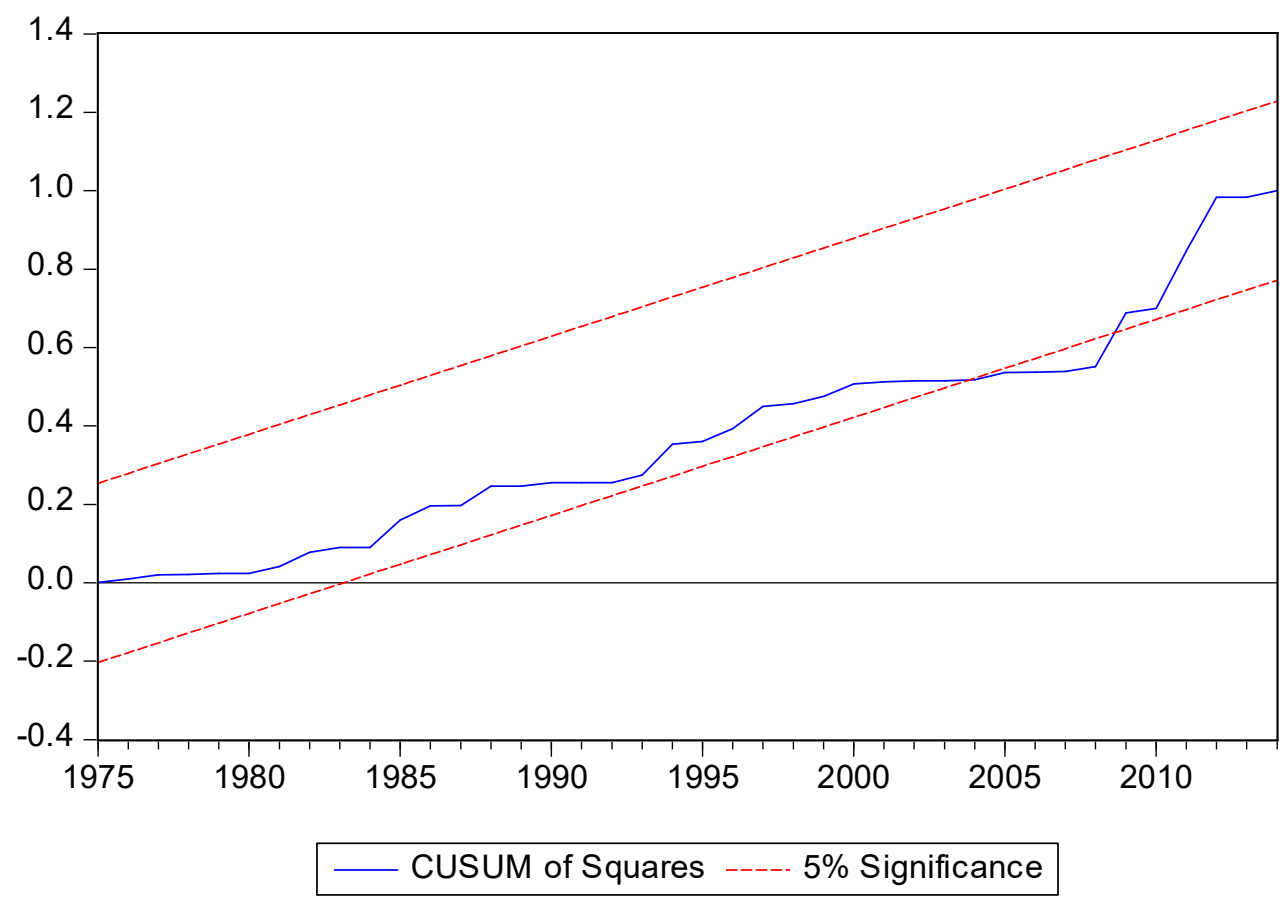

Figure-2: Plot of Cumulative Sum of Squares of Recursive Residuals 


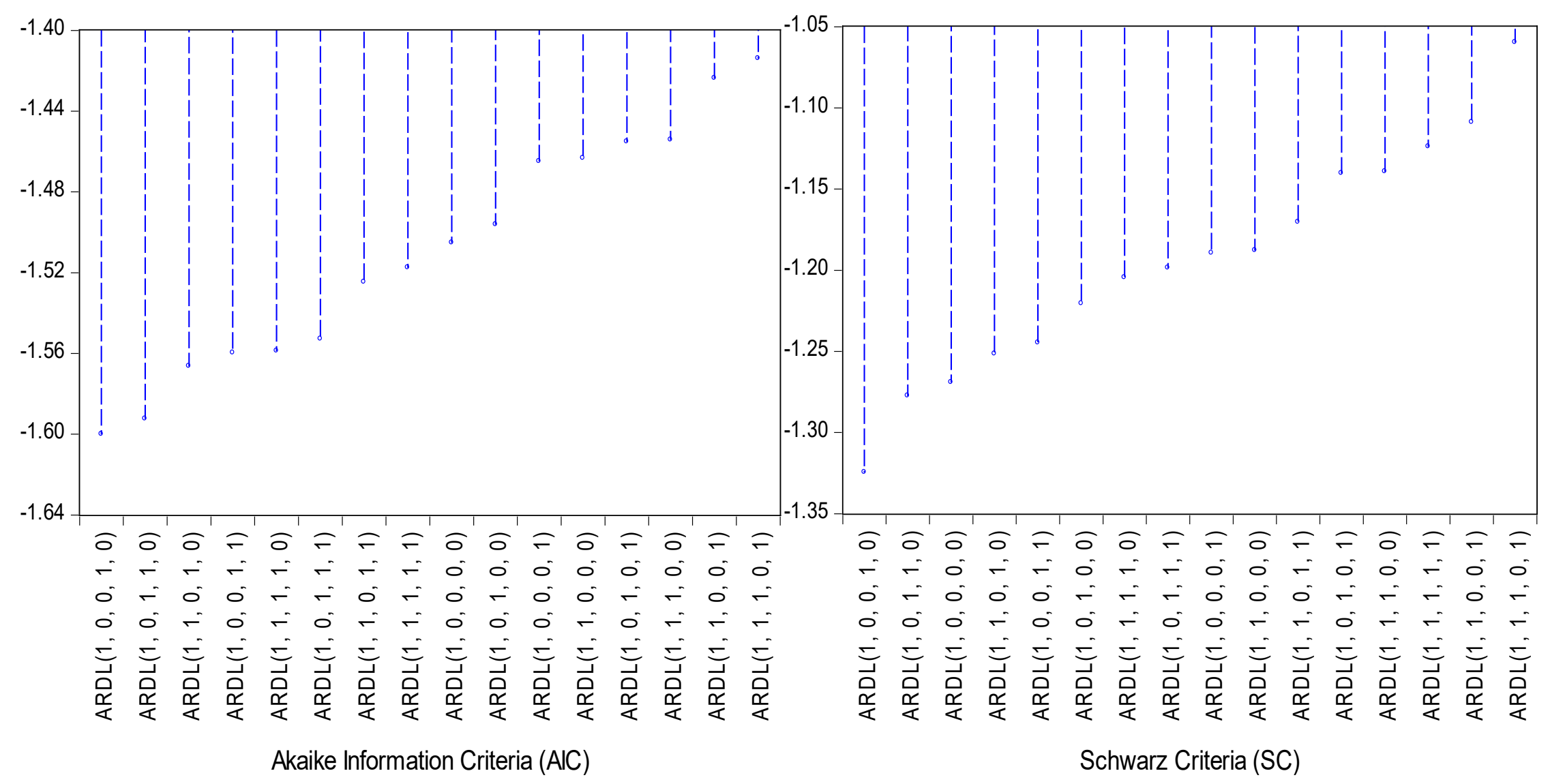

Figure-3: Model criteria graphs

Figure 3 indicates the best 16 several ARDL models computed by Eviews 9 based on the Akaike Information Criteria (AIC) and Schwarz information criterion (SC). In this paper we used the final ARDL $(1,0,0,1,0)$ model based on AIC. 


\section{Conclusions}

This present paper investigates the impact of climate change on rice production in Pakistan, by using annual time series data from 1968 to 2014. The ARDL bounds testing approach to contegration was used to check the existence of long-run relationship between climate change factors like emission of carbon dioxide and average temperature as well as other control variables such as area under rice crop and fertilizers offtake. The results show evidence of cointegration or long-run relationship between climate change and rice production in Pakistan. Furthermore, the climate change factors like emission of carbon dioxide and average temperature had positively impact on rice production in Pakistan, both in the long-run and the short-run. Likewise, the area under cultivation has a positive impact on rice production, both in long-run and short-run; whereas, the fertilizers also has positive impact on rice production in the long-run but it has a negative impact on rice production in the short-run. In Pakistan, climate change factors like $\mathrm{CO}_{2}$ and temperature have a positive effects on the rice production. However, about $60 \%$ population of Pakistan is living below the poverty line. Additionally, the population of Pakistan is growing very rapidly and in near future the country will face the issue of food security. So as to circumvent the issue of food insecurity of rice in future due to any adverse climate change effects, the government of Pakistan is required to increase rice cultivation area and have to support farmers by offering them fertilizers at subsidized prices.

\section{References}

Abid, M., Scheffran, J., Schneider, U. A., \& Elahi, E. (2018). Farmer Perceptions of Climate Change, Observed Trends and Adaptation of Agriculture in Pakistan. Environmental management, 1-14.

Abid, M., Ngaruiya, G., Scheffran, J., \& Zulfiqar, F. (2017). The Role of Social Networks in Agricultural Adaptation to Climate Change: Implications for Sustainable Agriculture in Pakistan. Climate, 5(4), 85.

Arshad M, Kächele H, Krupnik TJ, Amjath-Babu TS, Aravindakshan S, Abbas A, Mehmood Y, Müller K (2017). Climate variability, farmland value, and farmers' perceptions of climate change: implications for adaptation in rural Pakistan. Int J Sust Dev World 24(6):532-544. 
Arshad M, Amjath Babu TS, Kächele H, Müller K (2016). What drives the willingness to pay for crop insurance against extreme weather events (flood and drought) in Pakistan? A hypothetical market approach. Clim Dev 8(3):234-244.

Ali A and Erenstein O (2017). Assessing farmer use of climate change adaptation practices and impacts on food security and poverty in Pakistan. Clim Risk Manag 16:183-194.

Ali, S., Liu, Y., Ishaq, M., Shah, T., Ilyas, A., and Din, I. U. (2017). Climate change and its impact on the yield of major food crops: Evidence from Pakistan. Foods, 6(6), 39.

Bashir, M.K. (2010), "Institutional credit and rice productivity: a case study of District Lahore, Pakistan”, China Agricultural Economic Review, 2 (4): 412-419.

Buriro, A., Khooharo, A.A. and Ghulam, T. (2015), "Technical efficiency of rice production Sindh, Pakistan: a statistical analysis", Science International, 27(6):6225-6230.

Chandio, A.A., Jiang, Y., Rehman, A. and Dunya, R., (2018a). The linkage between fertilizer consumption and rice production: Empirical evidence from Pakistan. AIMS Agriculture and Food, 3(3): 295-305.

Chandio, A. A., Jiang, Y., Joyo, M. A., \& Pickson, R. B. (2018b). Research on Factors Influencing Grain Crops Production in Pakistan: An ARDL Approach. . European Online Journal of Natural and Social Sciences, .7(3):538-553.

Chandio, A.A. and Jiang, Y., (2018). Determinants of Adoption of Improved Rice Varieties in Northern Sindh, Pakistan. Rice Science, 25(2), pp.103-110.

Chandio, A.A., Jiang, Y., Gessesse, A.T. and Dunya, R. (2017), "The nexus of agricultural credit, farm size and technical efficiency in Sindh", Journal of the Saudi Society of Agricultural Sciences, doi:10.1016/j.jssas.2017.11.001.

Dickey, D. A and Fuller, W. A. (1981) Likelihood ratio statistics for autoregressive time series with a unit root. Econometrica 49(4), 1057-1079.

Elliott, G. (1999). Efficient tests for a unit root when the initial observation is drawn from its unconditional distribution. International Economic Review, 44, 767-784.

Elliott, G., Rothenberg, J. T., \& Stock, J. H. (1996). Efficient tests for an autoregressive unit root. Econometrica, 64, 813-836.

Engle, R. F and Granger, C. W. J., (1987) Cointegration and error correction representation: estimation and testing. Econometrica 55(2), 251-276. 
Ghulam, R., M. Afzal, M. Zahid and S. Bukhari. 2012. Climate Change in Pakistan Focused on Sindh Province. Technical Report No. PMD-25/2012 Pakistan Meteorological Department, Islamabad, Pakistan.

Gorst A, Groom B, Dehlavi A (2015). Crop productivity and adaptation to climate change in Pakistan. Working paper No. 214. Centre for Climate Change Economics and Policy, London, UK.

GOP, (2018). Pakistan Economic Survey 2017-18, Economic Advisor's Wing, Ministry of Finance, Government of Pakistan, Islamabad.

Hanif U, Syed SH, Ahmad R, Malik KA, Nasir M (2010). Economic impact of climate change on the agricultural sector of Punjab [with Comments]. Pak Dev Rev 4:771-798.

Hussain, A. (2012). Impact of credit disbursement, area under cultivation, fertilizer consumption and water availability on rice production in Pakistan (1988-2010)", Sarhad J. Agric, 28(1):95-101.

Janjua, P. Z., Samad, G., \& Khan, N. (2014). Climate change and wheat production in Pakistan: An autoregressive distributed lag approach. NJAS-Wageningen Journal of Life Sciences, 68, 13-19.

Johansen, S. and Juselius, K. (1990), "Maximum likelihood estimation and inference on cointegration - with application to the demand for money", Oxford Bulletin of Economics, 52:169-210.

Joyo, M.A., Ram, N. and Magsi, H. (2018). Risk Assessment of Climate Variability on Rice Productivity in Sindh Province of Pakistan. Pakistan Journal of Agriculture, Agricultural Engineering and Veterinary Sciences, 34(1): 79-88.

Kwiatkowski, D., Phillips, P. C. B., Schmidt, P., \& Shin, Y. (1992). Testing the null hypothesis of stationarity against the alternative of a unit root: How sure are we that economic time series have a unit root? Journal of Econometrics, 54, 159-178.

Magsi, H. and Sheikh, M.J. (2017). Seawater Intrusion: Land Degradation and Food Insecurity among Coastal Communities of Sindh. In: Bandyopadhyay S., Torre A., Casaca P. and Dentinho T. (ed.) Regional Cooperation in South Asia. Springer. Pp. 209-223.

Nomman, A. M., and Schmitz, M. (2011). Economic assessment of the impact of climate change on the agriculture of Pakistan. Business and Economic Horizons, 4(1), 1-12. 
Ng, S., Perron, P., (2001). Lag length selection and the construction of unit root test with good size and power. Econometrica, 69: 1519-1554.

Pesaran, M.H. (1997), "The role of economic theory in modelling the long-run”, Economic Journal, 107: 178-191.

Pesaran, M.H., and B. Pesaran, (1997). Working with Microsoft 4.0: An interactive approach, Oxford: Oxford University Press.

Pesaran, M.H., Shin, Y. and Smith, R.J. (2001), "Bounds testing approaches to the analysis of level relationships", Journal of Applied Econometrics, 16: 289-326.

Philips, P.C.B. and Perron, P. (1988), “Testing for a unit root in time series regression”, Biometrica, 75:335-346.

Rasul G, Mahmood A, Sadiq A, Khan S (2012). Vulnerability of the Indus delta to climate change in Pakistan Pak J Meteorol 8:89-107.

Siddiqui, R., G. Samad, M. Nasir, and H. H. Jalil (2012). The Impact of Climate Change on Major Agricultural Crops: Evidence from Punjab, Pakistan. The Pakistan Development Review $51: 4,261-276$.

Zhu T, Ringler C, Iqbal MM, Sulser TB, Goheer MA (2013). Climate change impacts and adaptation options for water and food in Pakistan: scenario analysis using an integrated global water and food projections model. Water International 3:651-669. 